\title{
Ecological effects of water-level fluctuations in lakes: an urgent issue
}

\author{
Karl M. Wantzen · Karl-Otto Rothhaupt • \\ Martin Mörtl · Marco Cantonati · \\ László G.-Tóth · Philipp Fischer
}

Water-level fluctuations (WLF) affect the ecological processes and patterns of lakes in several ways. Aquatic habitats and feeding or breeding grounds are gained or lost, as light, climate and wave impacts change to mention only a few phenomena. While the phenomenon of WLF has been studied in many rivers (better known as flood pulse, Junk \& Wantzen, 2004) and environmental flows (Bunn et al., 2006), so far it has not received due attention in lakes (Coops et al., 2003). A potential reason for why WLF in lakes have

Guest editors: K. M. Wantzen, K. O. Rothhaupt, M. Mörtl, M. Cantonati, L. G. Tóth \& P. Fischer

Ecological Effects of Water Level Fluctuations in Lakes

For the sake of brevity, the articles published in this special issue do not appear in the bibliography of this text.

K. M. Wantzen $(\bowtie) \cdot$ K. O. Rothhaupt · M. Mörtl

Limnologisches Institut der Universität Konstanz,

Mainaustraße 252, 78457 Konstanz, Germany

e mail: matthias.wantzen@uni konstanz.de

\section{Cantonati}

Limnology and Phycology Section, Museo Tridentino di Scienze Naturali, Via Calepina 14, 38100 Trento, Italy

\section{G. Tóth}

Balaton Limnological Research Institute of the Hungarian Academy of Sciences, 8237 Tihany, Hungary

P. Fischer

Biologische Anstalt Helgoland des Alfred Wegner Instituts, Kurpromenade 201, 27498 Helgoland, Germany been overlooked for such a long time may be that central Europe and North America the cradles of limnological research are situated in landscapes which have been shaped by man for long time. Most central European lakes have been regulated since the middle ages; therefore, naturally fluctuating lakes such as Lake Constance (Fig. 1) are rare today.

This lack of knowledge is most remarkable, as all climate change models consistently state that severe increases in climatic stochasticity can be anticipated and water availability will be reduced due to climate change (IPCC, 2001; Sophocleous, 2004). This means a decrease in snowfall and hence spring floods at mid- and high-elevations in temperate regions, which is countered by an increase of exceptionally strong rainfall events and severe droughts for all areas. Thus, there is an urgent need for comprehensive scientific approaches that address the impacts of WLF through socially and economically feasible mitigation schemes.

However, it needs to be stressed that WLF are natural patterns which are necessary for the survival of many species, i.e. natural WLF in lakes guarantee both productivity and biodiversity (Gafny et al., 1992; Gafny \& Gasith, 1999; Wantzen et al., 2002). Only extreme or untimely floods and droughts have deleterious effects for both biota and man (Sparks et al., 1998, Bond et al., 2008).

The dramatic effects of climate change that can be witnessed today (extreme droughts and floods) remind us of the necessity to implement studies to 

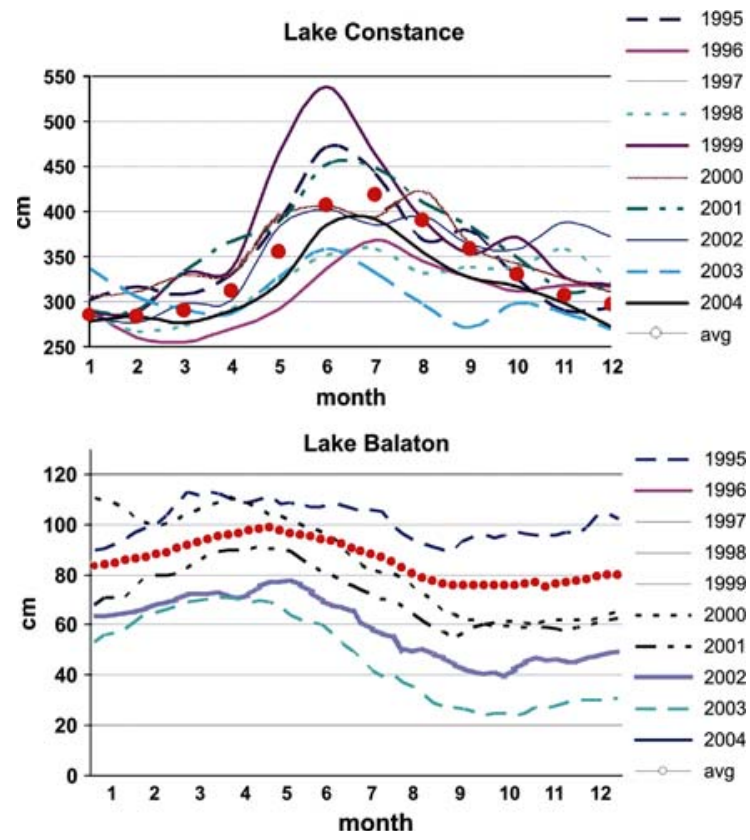

Fig. 1 Ten year series of hydrographs of Lake Constance (data: Konstanz harbour authorities) and of Balaton, the largest shallow lake in Central Europe (data by Varga, 2005). Mind different scales

develop environmentally and socially sound management schemes for future generations. Care must be taken not to replace one evil with another through over-regulation (thereby crippling) of naturally dynamic systems (an error repeatedly committed with rivers), but rather to increase the resilence and adaptability of lakes and their physical and social environments for future climate changes.

The following articles are an attempt to compile current knowledge on ecological effects of WLF in lakes. They span a wide range of geographic regions, morphological lake types and applied scientific disciplines. The publications presented here are the results of a workshop hosted by the collaborative research centre on lake littoral ecology at the University of Konstanz (SFB 454 Bodenseelitoral) in December 2005. Participants at this conference witnessed Lake Constance during an extreme drought of the lake which occurred that winter, exposing large parts of the littoral zone (Fig. 2) and causing dramatic reduction of the Dreissena mussel population in frostexposed zones, which are an important food source for water fowl (Werner et al., 2005). The recently reported invasive clam Corbicula fluminea also

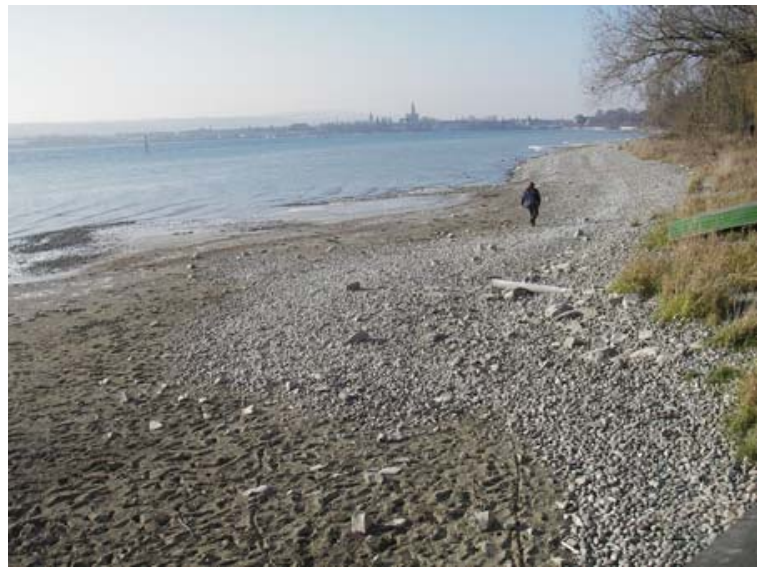

Fig. 2 The dry fallen littoral near Konstanz, December 2005. Photograph by Karl M. Wantzen

suffered a dramatic decline (Werner \& Rothhaupt, this issue) during this time.

The introduction is followed by an annotated bibliography (Leira \& Cantonati, this issue) which provides an overview of WLF's extensive literature since 1991 in an attempt to give this volume a more general perspective through its contributors. The term Water-Level Fluctuations (WLF) is not yet definitively defined. Hoffmann \& Lorke (this issue) suggest to extend the time-scale for WLF from seconds to hundreds of years as a temporal dimension and to discuss the equivalent spatial scale as data based on sets of lakes in different climatic zones.

WLF, especially pronounced floods, have been identified as major potential causes of reed decline (Dienst et al., 2004); however, the ultimate causes were not yet clear. Nechwatal et al. (this issue) showed that WLF and temperature have a significant influence on the performance of a reed-pathogen fungus, Pythium phragmitis, and suggest that predicted climate change events will help foster the development of this species.

In a study of WLF effects on littoral invertebrates in East-German lowland lakes, Brauns et al. (this issue) compared eulittoral and infralittoral habitats to simulate climate change-driven summer droughts. While species richness did not differ significantly, there was a significant change in the species communities consisting of coarse woody debris in the eulittoral habitats (with high abundances of beetles, mayflies and the functional feeding groups of piercers, predators and shredders) and the sandy 
habitats of the infralittoral. However, reed habitats might serve as refuges for these benthic invertebrates. This is indicated by the lack of significant differences between invertebrate communities developing on reed habitats in the eulittoral and infralittoral zones.

Baumgärtner et al. (this issue) studied the same question on stony substrates in a naturally fluctuating lake, Lake Constance, applying intensive temporal and spatial sampling efforts. They showed that the community patterns of the drift line were influenced by the previous water level. WLF accounted for most of the variation in these benthic communities. This finding was corroborated by White et al. (this issue) who studied the effects of natural water-level fluctuations in 16 small Laurentinian lakes. They found significant correlations between water quality parameters and WLF; however, among the biotic variables, only macroinvertebrates demonstrated significant relationships with WLF.

WLF potentially interfere with the influences that benthic macroinvertebrates exert on ecosystem functions. In Swedish lakes that experienced small WLF, invertebrate shredders were shown to be very influential on leaf-litter decomposition (Bjelke et al., 2004). However, Pabst et al. (this issue) did not observe strong impacts by this functional feeding group from the wave-impact zone in Lake Constance. Rather the wave action was important for physical degradation of leaves, as was indicated by experiments in wave mesocosms.

Boreal lakes often suffer from winter drawdown due to hydroelectric power plant operation in their tributary or outlet rivers. These WLF often cause freezing of the exposed littoral. In Finland, over 300 lakes (i.e. one-third of all inland water area) are regulated in such a fashion. Sutela \& Vehanen (this issue) studied WLF effects on fish communities in regulated and reference lakes in Finland by electrofishing. In spite of finding large differences in density (10.3 vs. 32.7 ind $\mathrm{m}^{-2}$, respectively), they were not really significant, because variables such as nutrient level and lake size affected the fish communities. Another study in Finnish lakes focused on macroinvertebrate assemblages in naturally fluctuating (maximum winter drawdown: $55 \mathrm{~cm}$ ) and regulated lakes (up to $675 \mathrm{~cm}$ winter drawdown). In this article, Aroviita \& Hämäläinen (this issue) revealed a strong decline in species richness with increasing amplitude in WLF. They identified indicator species sensitive to these effects. Keto et al. (this issue) presented the WLF-analysis tool "REGCEL" that was developed for the metric analysis of such impacts and to help implement successful sustainable management schemes in northern European countries.

In mediterranean regions, irrigation often consists of drawing water from lakes resulting in their shrinkage and increased eutrophication. The combination of summer drought and intense water use reinforces the severity of this problem. Skoulikidis et al. (this issue) showed that lowering of the water table exposes polluted sediments and mobilises toxics such as arsenic and chrome in a deep lake in Greece as well.

One article focused on WLF effects of invasive invertebrates in Lake Balaton where large sections of shore in the littoral have been covered by rip-rap. Balogh et al. (this issue) focused on a temporal decline of zebra mussels resulting from a drought in 2003, which exposed most of the rip-rap substrates. The plankton community including the planktonic larvae of Dreissena polymorpha was influenced by this drought as well.

The impacts of climate change on WLF and their effects on lake shores make an adaptive management plan necessary. Abrahams' (this issue) proposal uses Grime's CSR theory as a framework to assess such impacts and to develop practical management techniques for hydrological controls, substrate conditions, shoreline topography and vegetation establishment. Lastly, an overarching concept (Wantzen et al., this issue) was introduced based upon the flood pulse concept (Junk et al., 1989; Junk \& Wantzen, 2004), for use in developing categories of WLF and their interactions with lake ecosystem functioning.

These articles show the large variety of issues that involve WLF in lakes. When attempting to summarise the manuscripts for the current article, we found how many lacunae still exist and how necessary it is to intensify research in this interesting and important field of ecology.

Konstanz, 15.11.2007

The editors 


\section{References}

Bjelke, U., I. Bohmann \& J. Herrmann, 2004. Temporal niches of shredders in lake littorals with possible implications on ecosystem functioning. Aquatic Ecology 39: 4153.

Bond, R. B., P. S. Lake \& A. H. Arthington, 2008. The impacts of drought on freshwater ecosystems: An Australian per spective. Hydrobiologia 600: 316.

Bunn, S. E., M. C. Thoms, S. K. Hamilton \& S. J. Capon, 2006. Flow variability in dryland rivers: Boom, bust and the bits in between. River Research and Applications 22: 179186.

Coops, H., M. Beklioglu \& T. L. Crisman, 2003. The role of water level fluctuations in shallow lake ecosystems Workshop conclusions. Hydrobiologia 506 509: 2327.

Dienst, M., K. Schmieder \& W. Ostendorp, 2004. Effects of water level variations on the dynamics of the reed belts of Lake Constance. Limnologica 34: 2936.

Gafny, S. \& A. Gasith, 1999. Spatially and temporally sporadic appearance of macrophytes in the littoral zone of Lake Kinneret, Israel: Taking advantage of a window of opportunity. Aquatic Botany 62: 249267.

Gafny, S., A. Gasith \& M. Goren, 1992. Effect of water level fluctuation on shore spawning of Mirogrex terraesanctae (Steinitz), (Cyprinidae) in Lake Kineret, Israel. Journal of Fish Biology 41: 863871.

IPCC, 2001. Climate change 2001: Synthesis report. Inter governmental Panel on Climate Change (IPCC), Geneva, Switzerland.
Junk, W. J., P. B. Bayley \& R. E. Sparks, 1989. The flood pulse concept in river floodplain systems. Canadian Special Publication of Fisheries and Aquatic Sciences 106: 110127.

Junk, W. J. \& K. M. Wantzen, 2004. The flood pulse concept: New aspects, approaches, and applications an update. In Welcomme, R. \& T. Petr (eds), Proceedings of the 2nd Large River Symposium (LARS), Pnom Penh, Cambodia. Bangkok. RAP Publication: 117149.

Sophocleous, M., 2004. Global and regional water availability and demand: Prospects for the future. Natural Resources Research 13: 75.

Sparks, R. E., J. C. Nelson \& Y. Yin, 1998. Naturalization of the flood regime in regulated rivers. BioScience 48: 706 720 .

Varga, G., 2005. A Balaton vízháztartási viszonyainak viz sgálata (Study of the water regime of Lake Balaton). In Szlávik, L. (ed.), A Balaton (Lake Balaton) Vízügyi Közlemények, Különszám, Budapest: 93105.

Wantzen, K. M., F. A. Machado, M. Voss, H. Boriss \& W. J. Junk, 2002. Floodpulse induced isotopic changes in fish of the Pantanal wetland, Brazil. Aquatic Sciences 64: 239251.

Werner, S., M. Moertl, H. G. Bauer \& K. O. Rothhaupt, 2005. Strong impact of wintering waterbirds on zebra mussel (Dreissena polymorpha) populations at Lake Constance, Germany. Freshwater Biology 50: 14121426. 